\title{
MINERALOGICAL DIFFERENCES BETWEEN ANCIENT SHERDS AND EXPERIMENTAL CERAMICS: INDICES FOR FIRING CONDITIONS AND POST- BURIAL ALTERATION
}

\author{
Rathossi C. ${ }^{1}$, Pontikes Y. ${ }^{2}$ and Tsolis-Katagas P. ${ }^{1}$ \\ ${ }^{1}$ University of Patras, Department of Geology, Section of Earth Materials, 26500 Patras, Greece, \\ C.Rathosi@upatras.gr,N.Tsoli-Kataga@upatras.gr \\ ${ }^{2}$ Katholieke University of Leuven, Dept. of Metallurgy and Materials Engineering, Kasteelpark Arenberg 44, \\ B-3001, Heverlee,Leuven, Belgium, Yiannis.Pontikes@mtm.kuleuven.be
}

\begin{abstract}
Results are reported regarding laboratory-scale experimental work aiming to reproduce ceramic specimens with macro and micro characteristics similar to ancient sherds. Small differences in mineralogical composition between ancient sherds and experimental ceramics elucidated the effect of the firing conditions and the degree of post-burial alteration of ancient ceramics. Scarsity of gehlenite $\left(\mathrm{Ca}_{2} \mathrm{Al}_{2} \mathrm{SiO}_{7}\right)$ in sherds for which firing temperature has been estimated between 800 to $950^{\circ} \mathrm{C}$, led to higher $F \mathrm{~s} / \mathrm{Gh}$ (fassaite/gehlenite) ratio in respect to that recorded for the ceramic specimens. This fact is attributed to the dissolution of gehlenite during the post-burial alteration, the ancient ceramics were subjected to, but also due to the short sintering duration (i.e. higher heating rate and/or low soaking time) applied by the potters in some cases.
\end{abstract}

Key words: ancient ceramics, gehlenite, post-burial alteration, short firing cycle, Plio-Pleistocene sediments.

\section{Introduction}

The mineralogical transformation of calcareous clays during firing for the manufacture of ceramic products have been discussed by many authors (González-García et al. 1990; Dondi, et al. 1999, 1998; Riccardi et al. 1999; Cultrone et al. 2001; Bauluz et al. 2004). The formation of free CaO, after the thermal decomposition of calcite which starts at $\sim 600^{\circ} \mathrm{C}$ and completed around $800-850^{\circ} \mathrm{C}$, promotes nucleation of high temperature crystalline phases through reactions with the dehydroxylated phyllosilicate minerals. A series of phases including Ca-silicates of $\mathrm{Ca}$-Al-silicates such as wollastonite $\left(\mathrm{CaSiO}_{3}\right)$, gehlenite $\left(\mathrm{Ca}_{2} \mathrm{Al}_{2} \mathrm{SiO}_{7}\right)$, anorthite $\left(\mathrm{Ca}_{2} \mathrm{Al}_{2} \mathrm{Si}_{2} \mathrm{O}_{8}\right)$, fassaite or "ferrian aluminian diopside" according to the IMA, (Morimoto, 1988) ((Ca,Na)(Mg, $\left.\left.\mathrm{Fe}^{2+}, \mathrm{Fe}^{3+}, \mathrm{Al}, \mathrm{Ti}\right)(\mathrm{Si}, \mathrm{Al})_{2} \mathrm{O}_{6}\right)$ could be formed. Their presence in ancient sherds could aid to make inferences about the chemical composition of the raw materials employed by the ancient potters as well as the firing conditions (i.e. the maximum firing temperature, heating rate, soaking time and kiln redox atmosphere) they have followed. This information is essential for the establishment of the ancient technology.

However, the susceptibility of ancient ceramics to chemical weathering during their burial conditions must be carefully assessed. Dissolution phenomena and/or precipitation of minerals during post-burial alteration affect the mineralogical and geochemical composition of sherds, creating 
difficulties to establish, in a straightforward manner, the provenance of their raw materials and the determination of manufacturing technology (Heimann \& Maggetti, 1981; Owen \& Day 1996; Buxeda et al. 2002).

This paper is focused on the assessment of the reasons which affect the formation and stability of melilite phase (gehlenite) in ancient fine wares, a crucial mineral for the archaeometric investigation. Results are drawn by comparing mineralogical and petrographic data of ancient sherds with ceramics produced in the laboratory. The experimental ceramics are made of clay-rich raw materials which exhibited the best mineralogical and chemical affinity to the raw materials used in the ancient ceramics (Rathossi et al., 2003; Rathossi et al., 2004; Rathossi, 2005; Rathossi \& Pontikes, 2010a, b).

\section{Materials and Methods}

The ancient ceramic sherds are representative of Roman lamps (second half of the $1^{\text {st }} \mathrm{c}$. A.D. to early $4^{\text {th }}$ c. A.D.) derived from three excavations in the city of Patras which unearthed two workshops (A and B) and one Lychnomanteio (Fig. 1a). Lamps were found and collected from a depth of 1 to 1.5 $\mathrm{m}$. They are characterized as fine wares due to their fine grain size $(<0.2 \mathrm{~mm})$. Petrographic, mineralogical and geochemical study of 107 lamp sherds and 59 clay-rich samples collected from the prevailed Plio-Pleistocene sediments in the neighbour of the archaeological sites (Fig. 1b), established the local origin of raw materials for Roman lamps production (Rathossi et al., 2003; Rathossi, 2005). Detailed information concerning their sampling location and geology is provided in the aforementioned references. Three clay-rich samples from the Plio-Pleistocene formation (sampling location 1, 3, 4, Fig. 1b) were chosen, as they exhibited the highest degree of similarity with the ancient raw materials. The firing tests at the laboratory were performed at different conditions, in an effort to mimic the firing procedure applied in Roman times as reported in archaeometric investigations (Rathossi, 2005).

For the preparation of experimental ceramics, the clay-rich raw samples were gently crushed by hand in an agate mortar, without any refinement. The powder was mixed with water and the plastic mass was shaped by hand in discs, of $5 \mathrm{~cm}$ dia. by $1.5 \mathrm{~cm}$ height, approximately. After drying at room temperature for five days, the discs were placed in a resistance oven at $50{ }^{\circ} \mathrm{C}$ for $24 \mathrm{~h}$. Firing was performed in a resistance and a propane-firing kiln up to 850,950 and $1050{ }^{\circ} \mathrm{C}$. Heating and cooling rates in all firing experiments were $3{ }^{\circ} \mathrm{C} \mathrm{min}^{-1}$ and soaking time was $1 \mathrm{~h}$. Twenty-seven experiments were conducted; for each sample, three firing temperatures, in static air, oxidising and reducing atmosphere, were tested. The firing atmosphere in gas kiln was controlled by regulating the primary and secondary air flow; Bernoulli-type burners were used. Firing initiated in oxidising atmosphere and the transition to reducing atmosphere, where applicable, took place at $800{ }^{\circ} \mathrm{C}$ and throughout the soaking period. During cooling, the firing atmosphere was maintained and was inverted to oxidising for a temperature below $800{ }^{\circ} \mathrm{C}$. The measurement of the firing atmosphere was performed using a flue gas analyser employing electrochemical cells, measuring $\mathrm{O}_{2}$ and $\mathrm{CO}$ and calculating $\mathrm{CO}_{2}$ (Testo 335, Germany). A sample of hematite powder was placed next to the clay body during the firing tests in order to be used as diagnostic for the specific firing conditions. For oxidising firing, the ratio $\mathrm{CO} / \mathrm{CO}_{2}, \%$, ranged from 0.2 to 4.4 and for reducing firing, the ratio $\mathrm{CO} / \mathrm{CO}_{2}, \%$, ranged from 11.2 to 23.0 .

The chemical composition of the major elements for the ancient ceramics and clay-rich samples was determined by Inductively Coupled Plasma-Optical Emission Spectrometry (ICP-OES) at ACTLABS, Ancaster, Ontario, Canada. Detection limit for major elements is $0.01 \%$. The analytical precision calculated from replicate analysis of one sample is better than $\pm 1 \%$. 

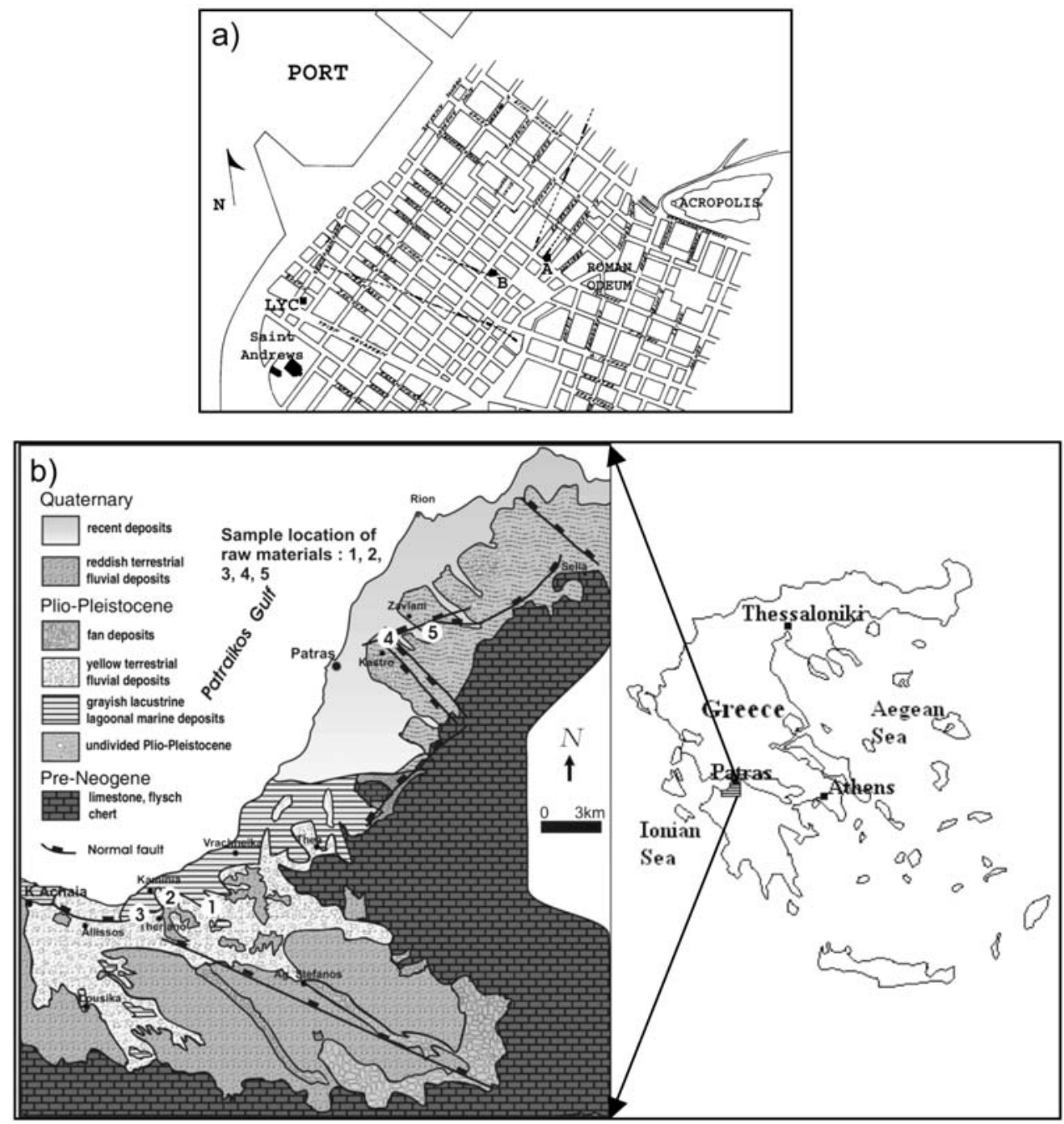

Fig. 1: a. Part of the town-plan of the city of Patras with the location sites of excavations, the two workshops (A and B) and the Lychnomanteion (LYC). Dashes lines indicate ancient roads (Petropoulos, 1999); b. Simplified geological map of Northwestern Peloponnese. Numbers refer to sampling locations. Lithofacies after Loftus \& Tsoflias (1971), Zelilidis et al. (1988) and tectonic data after Doutsos et al., 1988.

Cross-sections of the ancient sherds, clay-rich samples and their ceramic specimens were mounted on glass, sectioned to a thickness of 30-40 $\mu \mathrm{m}$, and polished for analysis by polarizing and scanning electron microscope (JEOL 6300). Powdered samples were also subjected to X-ray diffraction (Bruker D8 Advance, equipped with a LynxEye ${ }^{\circledR}$ detector) studies to determine the high-temperature crystalline phases formed during firing in both ancient ceramics and test samples. The scanning area covered the $2 \theta$ interval $2-70^{\circ}$, with a scanning angle step of $0.015^{\circ}$ and a time step of $0.3 \mathrm{~s}$. Qualitative analysis was performed by the DIFFRAC ${ }^{\text {plus }}$ EVA ${ }^{\circledR}$ software (Bruker-AXS) based on the ICDD Powder Diffraction File. The mineral phases were quantified using a Rietveld-based quantification routine with the TOPAS ${ }^{\circledR}$ software (DIFFRAC ${ }^{\text {plus }}$ TOPAS Ver. 3.0 Tutorial, Bruker-AXS). 


\section{Results and Discussion}

Roman lamps were made by $\mathrm{Ca}$-rich raw materials with a significant $\mathrm{Fe}_{2} \mathrm{O}_{3}$ content $(\mathrm{CaO} \approx 10$ wt $\%$, $\mathrm{Fe}_{2} \mathrm{O}_{3} \approx 7 \mathrm{wt} \%$ ). Plotting the bulk chemical composition of ancient sherds on the ternary diagram $(\mathrm{Ca}, \mathrm{Mg}, \mathrm{Fe}) \mathrm{O}-(\mathrm{Al}, \mathrm{Fe})_{2} \mathrm{O}_{3}-\mathrm{SiO}_{2}$ falls in the field of Quartz-Anorthite-Diopside+Wollastonite, suggesting that during firing the mineralogical transformations include gehlenite as a metastable newphase (Fig. 2a). Hence, gehlenite is expected to have been crystallized in higher amount than clinopyroxene in low fired lamps $\left(\mathrm{T} \approx 800^{\circ} \mathrm{C}\right)$. In lamps fired at temperature higher than $1000^{\circ} \mathrm{C}$ or for prolonged retention at the maximum temperature, the gelhenite content is expected to have been diminished as it is reacted with residual quartz towards anorthite and wollastonite (Peters \& Iberg, 1978; Riccardi et al., 1999; Traoré et al., 2000).

The above-mentioned expected trend, well documented in the literature, seems to be in contradiction with the mineralogical results recorded for ancient sherds. X-ray diffraction analyses of Roman lamp sherds fired at low temperature $800-900^{\circ} \mathrm{C}$ show higher amount of clinopyroxene (fassaite) compared to gehlenite. The latter mineral, in the studied sherds, is present as a minor constituent, even if at these temperatures the formation of gehlenite in Ca-rich ceramics is expected to be intense. The estimation of the firing temperature of the ancient sherds is based on the preservation of the basal reflections $(001,110)$ of white mica and their low content in new high-T mineral phases (Maggetti, 1981; Cultrone et al. 2001; Rathossi \& Pontikes 2010a). The preservation of mica suggests that the neo-crystallization is in early stages.

The very low amount of gehlenite in Roman lamps at low temperature $\left(\mathrm{T} \approx 800-850^{\circ} \mathrm{C}\right)$ is predominantly attributed to the mineralogical/chemical composition and the grain-size distribution of their raw materials. In detail, to the:

(i) very fine grained calcite (micrite and/or sparite) in the majority of samples,

(ii) homogeneous dispersion of calcite in the micromass and

(iii) $\mathrm{CaO}$ content, which ranges between 5 and $15 \mathrm{wt} \%$

These reasons favour the crystallization rate of clinopyroxene (fassaite) at the expense of gehlenite, already from $800^{\circ} \mathrm{C}$ (Peters \& Jenni, 1973; Noll, 1978; Maniatis \& Tite, 1981; Veniale, 1990).

In addition, three more hypotheses are being forward:

1. The burial conditions of ceramics have an impact on the alteration phenomena.

According to Heimann \& Maggetti, (1981), Nomura \& Miyamoto, (1995) and Wang \& Becker, (2009) during burial processes, ambient conditions, i.e. $\mathrm{CO}_{2}$-charged solutions of $\mathrm{pH} 6$, could lead to the complete breakdown of gehlenite and the subsequent formation of wairakite $\left(\mathrm{Ca}\left(\mathrm{AlSi}_{2} \mathrm{O}_{6}\right) 22 \mathrm{H}_{2} \mathrm{O}\right)$, calcite and probably small amounts of Ca-montmorillonite or to the formation of scawtite $\left(\mathrm{Ca}_{7}\left(\mathrm{CO}_{3}\right)\left(\mathrm{Si}_{6} \mathrm{O}_{18}\right) 2 \mathrm{H}_{2} \mathrm{O}\right)$. Gehlenite could be decomposed also under the conditions of a humid climate (humid acid, sodium salt, with $\mathrm{CO}_{2}$-charged solutions, $\mathrm{pH} 8.5$ ) or under the presence of a $\mathrm{Na}_{2} \mathrm{CO}_{3}$ solution. Ca could be extracted from gehlenite due to a high chemical potential of $\mathrm{CO}_{2}$ and metastable vaterite and small traces of aragonite are formed. Both gradually transform to calcite, the most stable polymorph. $\mathrm{Al}$ and $\mathrm{Si}$ (residue of decomposed gehlenite by the $\mathrm{Ca}$ extraction) could react with $\mathrm{Na}$ in a fluid to form analcite or (hydro) sodalite.

Alternatively, according to Nomura and Miyamoto (1998), organic carbon might react with $\mathrm{O}_{2}$ in the fluid to generate $\mathrm{CO}_{3}{ }^{2-}$ under oxidising conditions. Then gehlenite is attacked by the $\mathrm{CO}_{3}{ }^{2-}$-rich fluid to generate a $\mathrm{Ca}^{2+}$ rich fluid from which calcite crystallized. The dissolution of gehlenite by the fluid also releases $\mathrm{Al}$ and $\mathrm{Si}$ ions (into the fluid), and together with $\mathrm{Na}$, which may dissolve from the glassy matrix, could form (hydro) sodalite or other aluminosilicates. 

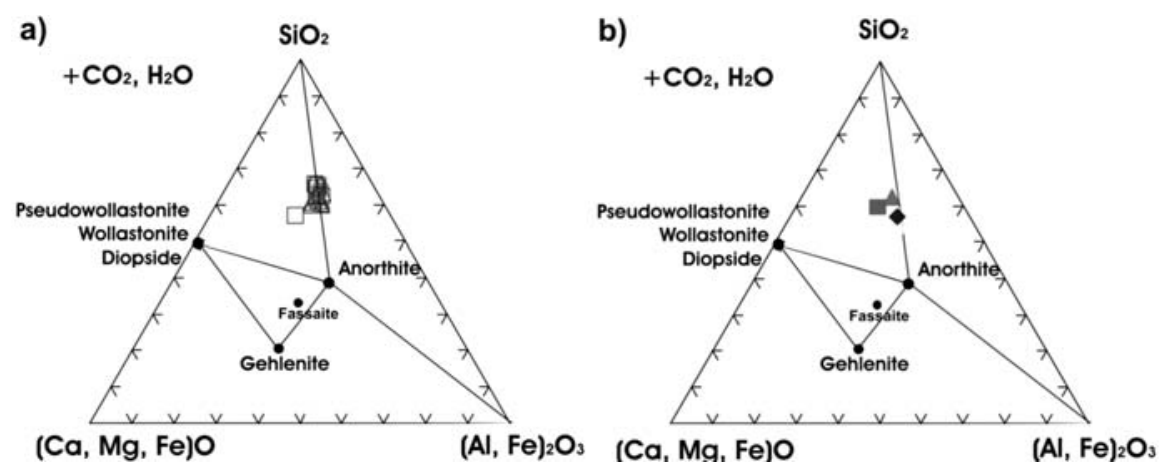

Fig. 2: $(\mathrm{Ca}, \mathrm{Mg}, \mathrm{Fe}) \mathrm{O}-(\mathrm{Al}, \mathrm{Fe})_{2} \mathrm{O}_{3}-\mathrm{SiO}_{2}$ plot of chemical composition of : (a) Representative Roman lamps from the three excavations (open square= workshop A; open triangle $=$ workshop B; open rhomb= Lychnomanteion; see also Table 1a) and (b) three clay-rich raw materials used in experimental work (full square $=$ sampling location 1; full rhomb= sampling location 4; full triangle= sampling location 5; see also Table $1 \mathrm{~b}$ ).

Except of calcite, no reflections of wairakite and Ca-montmorillonite or analcite and (hydro)sodalite have been detected in X-ray patterns of ancient ceramics considered in this study, whereas the presence of scawtite can not be resolved because its basal peak $(3.02 \AA)$ overlaps with the basal peak of calcite ( $3.03 \AA$ ). As gehlenite seems to be more susceptible to aqueous alteration compared to clinopyroxene and anorthite and in combination with the detection of calcite in Roman lamps, it cannot be precluded the possibility of a slightly chemical weathering of lamps during burial processes.

2. The thermal stability of gehlenite is affected by the redox atmosphere in the kiln.

Concerning the influence of firing conditions on the thermal stability of gehlenite, a plausible hypothesis is the effect of redox atmosphere in the kiln. Indeed, the crystallization of Al-Fe-rich clinopyroxene (fassaite) in ancient sherds indicates a high oxygen fugacity $\mathrm{fO}_{2}$ approaching or slightly exceeding the HM buffer (Hijikata \& Okuma, 1969; Onuma \& Yagi, 1975; Oba \& Onuma, 1978; Onuma et al., 1981; Onuma, 1983). Thus, it could be assumed that the oxidising conditions
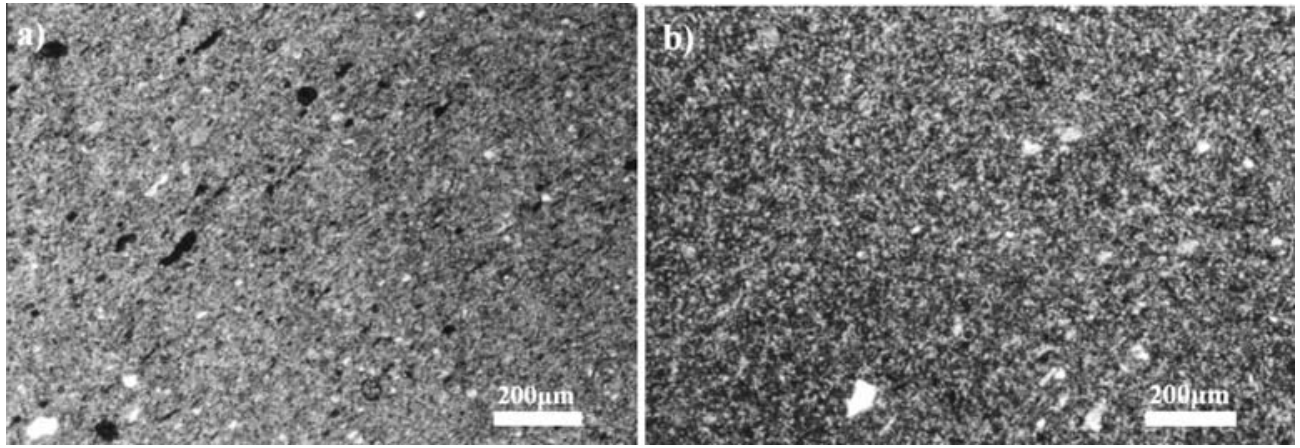

Fig. 3: Representative photomicrographs displaying the similarity of the petrographic fabrics between (a) a very low fired roman lamp $\left(\mathrm{T} \approx 650^{\circ} \mathrm{C}\right)$ and (b) a local clay-rich sample (from sampling location 4 in Fig. 1b), representative of the raw material of ancient sherds, which was used in the experimental work. The lighter colour of ancient sherd micromass results from the firing procedure. 



Fig. 4: Variation of the Fs/Gh (fassaite/gehlenite) ratio (a) and of wt\% calcite content (b) in respect to various firing temperatures in Roman lamps and in experimental ceramics at the three atmosphere conditions considered in this study.

which prevailed in ancient kilns influenced the formation of gehlenite. However, the firing experiments on the three local clay-rich samples best representative of Roman lamps' raw materials in relation to chemical composition, mineralogy and grain-size distribution, (Fig. 2b, Fig. 3), did not result to a clear correlation between firing conditions tested and degree of formation for gehlenite. Specifically, the X-ray diffraction analysis of experimental ceramics fired at $850^{\circ} \mathrm{C}$, determined that gehlenite is formed at considerable amounts (Rathossi \& Pontikes, 2010a, b), contrary to the lower amounts in ancient lamp sherds fired between 800 and $900^{\circ} \mathrm{C}$ (Fig. 4a).

3. The duration of firing cycle influences the thermal stability of gehlenite.

The petrographic observation was a powerful tool in combination with X-ray diffraction analysis to clarify better that the sintering duration is one of the reasons for the low amount of gehlenite in ancient sherds. During petrographic and mineralogical analyses, the presence of calcite (Fig. 4b) is detected even in samples fired at high temperatures $\left(\mathrm{T}=1000-1050^{\circ} \mathrm{C}\right)$ where fassaite and anorthite dominate. The simultaneous coexistence of calcite with high-T minerals practically eliminates any hypothesis of primary calcite, strengthening the assumption of a secondary's origin calcite, i.e. formed by:

(i) filtration of calcareous aqueous solutions during burial conditions, followed by the recrystallization of secondary calcite,

(ii) secondary calcite formed by the decomposition of gehlenite under post-burial chemical leaching and

(iii) the recarbonation of portlandite $\left[\mathrm{Ca}(\mathrm{OH})_{2}\right]$ generated by the hydration of unreacted lime $(\mathrm{CaO})$

In particular, analysis on the petrographic fabric of several high fired sherds $\left(\mathrm{T}=1000-1050^{\circ} \mathrm{C}\right)$, revealed either pores filled with calcite crystals forming blocky aggregates and/or needles of calcite with chaotic spatial orientation (calcitic hypo-coating, Fig. 5a) or concentration features (i.e. speckled, striated b-fabric, Kemp 1985) formed by calcite dispersed in a optically inactive micro-mass (Fig. 5b, 5g). In the latter case, calcite could be derived from either the alteration of gehlenite or the unreacted lime.

In lamp sherds fired at lower temperature, between 800 and $900^{\circ} \mathrm{C}$, residual lime and/or incompletely dissociated calcite have been observed (Fig. 5c, 5e, 5f). Moreover, X-ray diffraction analysis of sherds 

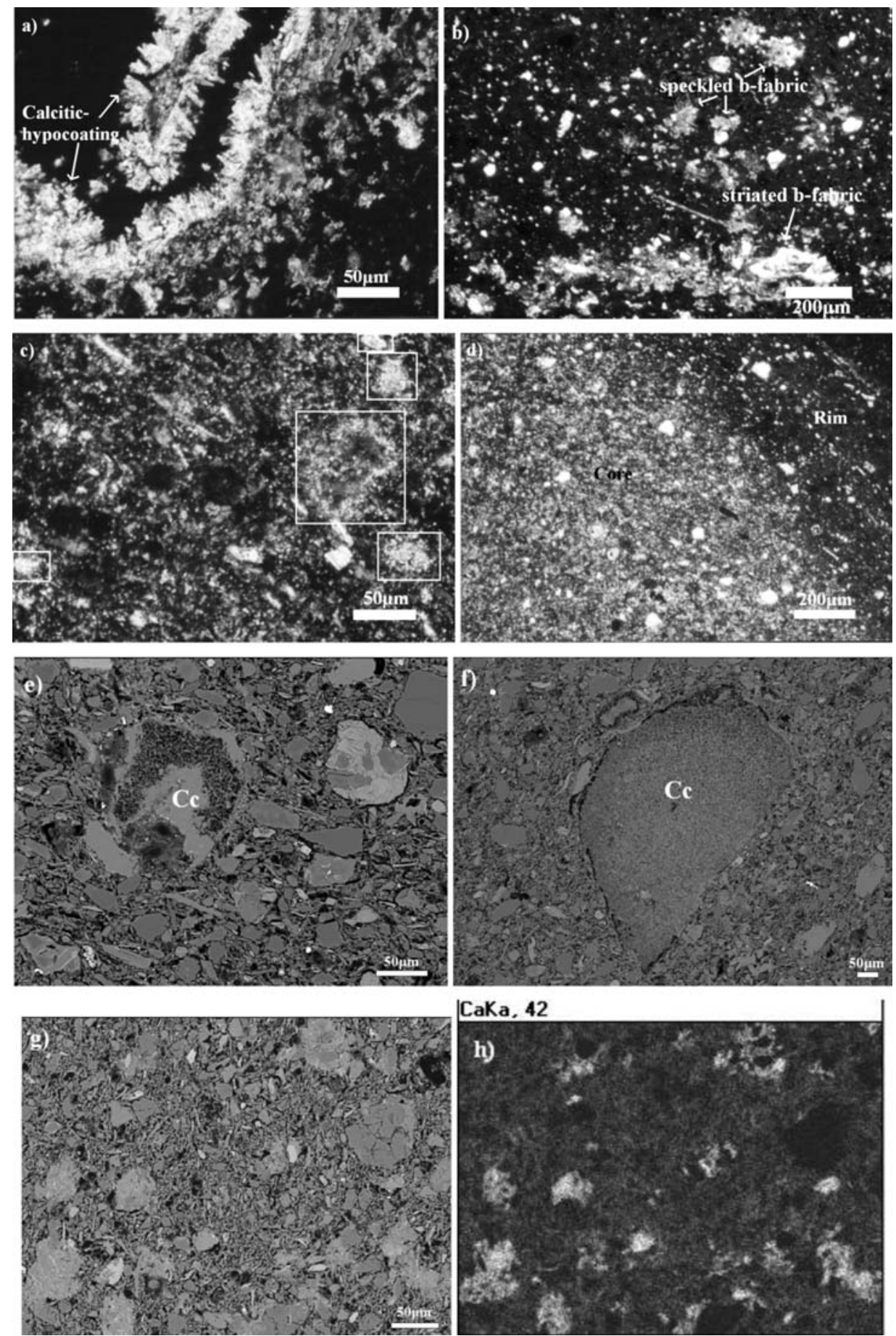

CaKa, 42

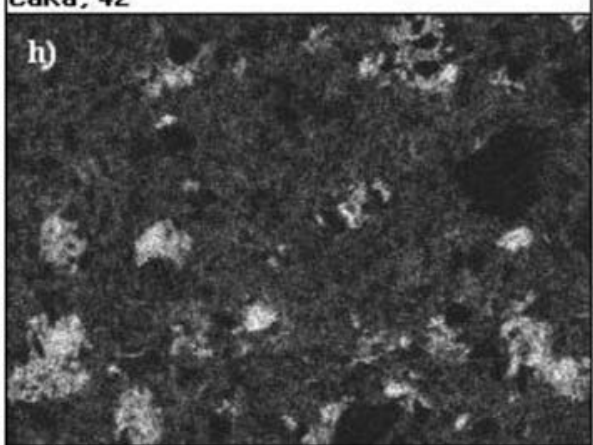

Fig. 5: Representative photomicrographs of Roman lamps, $\left(\mathrm{a}: \mathrm{T} \approx 1050^{\circ} \mathrm{C} ; \mathrm{b}: \mathrm{T} \approx 1050^{\circ} \mathrm{C} ; \mathrm{c}: \mathrm{T} \approx 800^{\circ} \mathrm{C} ; \mathrm{d}: \mathrm{T} \approx 950^{\circ} \mathrm{C}\right.$; all in crossed polars). Representative back scattered electron micrograph (e: $\mathrm{T} \approx 900^{\circ} \mathrm{C} ; \mathrm{f}: \mathrm{T} \approx 900^{\circ} \mathrm{C} ; \mathrm{g}: \mathrm{T} \approx 1050^{\circ} \mathrm{C} ; \mathrm{h}$ : mapping of $\mathrm{Ca}$ in sample $\mathrm{g})$. Rectangular shape and $(\mathrm{Cc})$ indicate residual lime and partially decomposed calcite. 
indicated that calcite content at those temperatures reached up to $16 \mathrm{wt} \%$, when in experimental ceramics fired at $850^{\circ} \mathrm{C}$ the concentration did not exceed $4 \mathrm{wt} \%$ (Fig $4 \mathrm{~b}$ ). In these low fired sherds, the ratio $\mathrm{Fs} / \mathrm{Gh}$ is very high compared with that in experimental ceramics at $850^{\circ} \mathrm{C}$ (Fig. 4).

Additionally, optical observation showed that ceramic bodies of lamps often exhibit zoning with an optically inactive rim (the firing has been completed) alternating with an optically active (high birefringence) core in which primary micrite calcite grains and/or residual lime dominate (Fig. 5d). Their firing temperature is estimated around $950^{\circ} \mathrm{C}$ as evidenced by the higher content of new phases (fassaite, anorthite) and the absence of white mica, suggesting that its dehydroxylation has been completed. For these sherds, gehlenite content is also lower than that in experimental ceramics at the same temperature (Fig. 4).

These specific features in the lamp sherds fired between 800 and $950^{\circ} \mathrm{C}$, which were not detected in the experimental ceramics, suggest a shorter overall firing duration (i.e. higher heating rate and/or shorter soaking period) in the ancient kiln. This fact led to a limited progress of mineralogical transformation across the ceramic body (partially decomposed calcite and/or residual lime). According to Moroni \& Conti (2006) at $850^{\circ} \mathrm{C}$ the lime amount increases significantly at high heating rate and short soaking period whereas quantities of gehlenite tend to decrease drastically when heating rate increases. This happens due to the crystallization of new phases is governed by the kinetics of dehydroxylation and decarbonation reactions which in turn are controlled by the heating rate and soaking time.

Another factor which affects ceramic transformation is the shape of lamps (closed form), since this geometry hinders the entrance of hot gases to the interior (zoning, primary calcite preserved in core). Finally, the efficiency of kiln is one more reason which must be taken into account for the uncompleted decomposition of calcite or unreacted calcite. Modern kilns reach an efficiency of $30-85 \%$ whereas the efficiency of kilns in antiquity reached $20 \%$ at best, therefore the energy required for the decarbonation reaction was not readily available in ancient kilns (Freidin \& Meir, 2005).

All these factors, during the firing of lamps, provoked the limited decarbonation reaction released $\mathrm{CaO}$ in the system which was sufficient to participate in the crystallization of fassaite rather than gehlenite. For the latter mineral the content of $\mathrm{CaO}$ in its structure is around 30wt\% (Deer et al., 1986).

\section{Conclusions}

The comparison between Roman lamps and experimental ceramics gave a very good correlation in petrography, mineralogy, microstructure and microchemistry (Rathossi, 2005; Rathossi \& Pontikes, 2010a,b). The only difference lies in the lower rate of gehlenite's crystallization in Roman lamps. A higher proportion of Fs/Gh ratio results in comparison with that in experimental ceramics which could be ascribed to the following two basic reasons :

a) the post-burial alteration of ancient sherds, which led to the dissolution of gehlenite and the formation of secondary calcite and

b) the shorter sintering duration (i.e. higher heating rate and/or lower soaking time) applied by the ancient potters. Such a practise would prevent the complete mineralogical transformations in the ceramic body. Calcite has been detected in lamp sherds fired up to $950{ }^{\circ} \mathrm{C}$ suggesting either the artial decomposed calcite or residual lime as the sintering duration was not enough to complete the neo-crystallization. 


\section{Acknowledgments}

We are thankful to Dr. M. Petropoulos, Director of $\Lambda \Theta^{\prime}$ Ephorate of Prehistoric and Classical Antiquities, Tripoli, Greece, for providing the ancient sherds.

\section{References}

Bauluz, B., Mayayo, M.J., Yuste, A., Fernandez-Nieto, C., Gonzalez Lopez, J. M. 2004. TEM study of mineral transformations in fired carbonated clays: relevance to brick making.Clay Minerals, 39, PP. 333-344.

Buxeda i Garrigós, J., Mommsen, H., Tsolakidou, A. 2002. Alterations of $\mathrm{Na}, \mathrm{K}$ and Rb concentrations in Mycenaean pottery and a proposed explanation using X-Ray Diffracrion. Archaeometry, 44, pp. 187-198.

Cultrone, G., Rodriguez-Navarro, C., Sebastian, E., Cazalla, O., De La Torre, M. J. 2001. Carbonate and silicate phase reactions during ceramic firing. European Journal of Mineralogy, 13, (3), pp. 621-634.

Deer, W.A., Howie, R.A., Zussman, J. 1986. Rock-forming minerals, (2nd edition), v. 1B,

Disilicates and Ring Silicates. Publish by the Geological Society, pp. 285-334.

Dondi, M., Ercolani, G., Fabbri B., Marsigli, M. 1999. Chemical composition of Melilite formed during the firing of Carbonate-rich and Iron-containing ceramic bodies. Journal of the American Ceramic Society, 82, (2), pp. 465-468.

Dondi, M., Ercolani, G., Fabbri, B., Marsigli, M. 1998. An approach to the chemistry of pyroxenes formed during the firing of Ca-rich silicate ceramics. Clay Minerals, 33, (2-3), pp. 443-452.

Doutsos, T., Kontopoulos, N., Poulimenos, G. 1988. The Corinth-Patras rift as the initial stage of continental fragmentation behind an active island arc (Greece). Basin Research, 1, pp. 177-190.

Freidin, C., Meir, I.A. 2005. Byzantine mortars of the Negev Desert. Construction and Building Materials, 19, pp. 19-23.

González-García, F., Romero-Acosta, V., García-Ramos, G., González-Rodríguez, M. 1990. Firing transformations of mixtures of clays containing illite, kaolinite and calcium carbonate used by ornamental tile industries. Applied Clay Science, 5, 4, pp. 361-375.

Heimann, R. B., Maggetti, M. 1981.Experiments on simulated burial of calcareous Terra Sigillata (mineralogical change). Preliminary results, in Scientific studies in ancient ceramics (ed. M. J. Hughes), pp. 163-77, British Museum Occasional Paper 19, London.

Hijikata, K., Okuma, K. 1969. Phase equilibria of the system $\mathrm{CaMgSi}_{2} \mathrm{O}_{6}-\mathrm{CaFe}^{3+} \mathrm{AlSiO}_{6}$ in air. Japan Assoc. Miner. Petrol. And Econ. Geolog. J., 62, pp. 209-217.

Kemp, R.A. 1985. Soil Micromorphology and the Quaternary. Quartenary Research Association Technical Guide, No 2, Cambridge.

Loftus, D.L., Tsoflias, P. 1971.Geological map of Greece, Nafpaktos sheet scale 1:50.000. Institute of Geology and Mineral Exploration, Athens.

Maggetti, M., 1981. Composition of Roman pottery from Lousonna (Switzerland). In: Hughes, M.J. (Ed.), Scientific Studies in Ancient Ceramic. British Museum Occasional Papers, v19, pp. 33- 49.

Maniatis, Y., Tite, M.S. 1981. Technological examination of Neolithic - Bronze Age pottery from central and southeast Europe and from the Near East, Journal of archaeological Science, 8, pp. 59-76.

Morimoto, N. 1988. Nomenclature of pyroxenes. American Mineralogist, 73, pp. 1123-1133.

Moroni, B., Conti, C. 2006. Technological features of Renaissance pottery from Deruta (Umbria, Italy): An experimental study. Applied Clay Science, 33, (3-4), pp. 230-246.

Noll, W. 1978. Mineralogie and Technik der bemalten Keramiken Altägyptens. Neues Jahrbuch fürMineralogie, Abhandlungen, 133, 3, pp. 227-290.

Nomura, K., Miyamoto, M. 1995. Hydrothermal Experiments on Refractory Minerals Related to CAIs: Implications for Aqueous Alteration in Parent Bodies. Meteoritics, 30, no 5, pp. 558. 
Nomura, K., Miyamoto, M. 1998. Hydrothermal experiments on alteration of Ca-Al-rich inclusions (CAIs) in carbonaceous chondrites: Implication for aqueous alteration in parent asteroids. Geochimica et Cosmochimica Acta, 62, 21/22, pp. 3575-3588.

Oba, T., Onuma, K. 1978. Preliminary report of the join $\mathrm{CaMgSi}_{2} \mathrm{O}_{6}-\mathrm{CaFe}^{3+} \mathrm{AlSiO}_{6}$ at low oxygen fugacity. Journal of the Faculty of Science, Hokkaido University, 18, pp. 433-444.

Onuma, K. 1983 Effect of oxygen fugacity on fassaitic pyroxene. Journal of the Faculty of Science, Hokkaido University, IV, (20), pp. 185-194.

Onuma, K., Akasaka, M. Yagi, K. 1981.The bearing of the system $\mathrm{CaMgSi}_{2} \mathrm{O}_{6}-\mathrm{CaAl}_{2} \mathrm{SiO}_{6}-\mathrm{CaFe} \mathrm{AlSiO}_{6}$ on fassaitic pyroxene. LITHOS, 14, (3), pp. 173-182.

Onuma K., Yagi, K. 1975. The join $\mathrm{CaMgSi}_{2} \mathrm{O}_{6}-\mathrm{CaAl}_{2} \mathrm{SiO}_{2} \mathrm{O}_{6}-\mathrm{CaFe}^{3+} \mathrm{AlSiO}_{6}$ in air and its bearing on fassaitic pyroxene. Journal of the Faculty of Science, Hokkaido University, IV, (16), pp. 343-356.

Owen, V., Day, T.E. 1996. Assessing and Correcting the Effects of the Chemical Weathering of Potsherds: A Case Study Using Soft-Paste Porcelain Wasters from the Longton Hall (Staffordshire) Factory Site. Geoarchaeology, 13, 3, pp. 265-286.

Peters, T.J., Jenny, J.P. 1973. Mineralogical study of the firing characteristics of brick clays. Beitr. Geol. Schweitz Geotechen. 50, pp. 59, Switzerland.

Peters, T., Iberg, R. 1978. Mineralogical changes during firing of calcium-rich brick clays. Ceramic Bulletin, 57, pp. 503-509.

Petropoulos, M. 1999. Roman Lamp Workshops at Patras and the Lychnomanteion. Archaeological Bulletin, vol. 70. Ministry of Cultural Heritage, Athens, Greece.

Rathossi, C., Katagas, C., Tsolis-Katagas, P., 2003. Major and trace element characterization of Archaic and Roman pottery from Achaia, Greece. In: Isabel Prudêncio, M., Isabel Dias, M. and Waerenborgh, J. C., (Eds), Understanding people through their pottery, 7th European Meeting on Ancient Ceramic (EMAC'03), pp. 217-228.

Rathossi, C., Tsolis-Katagas P., C. Katagas, C., 2004. Technology and composition of Roman pottery in northwestern Peloponnese, Greece. Applied Clay Science, 24, (3-4), pp.313-326.

Rathossi, C., 2005. Ancient ceramics from NW Peloponnese and the provenance of their raw materials: a petrographic, mineralogical, geochemical and archaeometric approach. $\mathrm{PhD}$ thesis, University of Patras.

Rathossi, C., Pontikes, Y. 2010a. Effect of firing temperature and atmosphere on ceramics made of NW Peloponnese clay sediments. Part I: reaction paths, crystalline phases, microstructure and colour. Journal of the European Ceramic Society (in press)

Rathossi, C., Pontikes, Y. 2010b. Effect of firing temperature and atmosphere on ceramics made of NW Peloponnese clay sediments. Part II: chemistry of pyrometamorphic minerals and comparison with ancient ceramics. Journal of the European Ceramic Society (in press)

Riccardi, M.P., Messiga, B., Duminuco, P. 1999. An approach to the dynamics of clay firing. Applied Clay Science 15, pp. 393-409.

Traoré, K., Kabré, T.S., Blanchart, P. 2000. Low temperature sintering of a pottery clay from Burkina Faso. Applied Clay Science 17, pp. 279-292.

Veniale, F. 1990. Modern techniques of analysis applied to ancient ceramics. In: Veniale, F., Zerra, U. (Eds.), Proc. ICOMOS-CE Workshop, Advanced Workshop: Analytical Methodologies for the Investigation of Damaged Stones, Pavia, Italy, pp. 1 -45.

Wang, J., Becker, U. 2009. Structure and carbonate orientation of vaterite $\left(\mathrm{CaCO}_{3}\right)$. American Mineralogist, 94, pp. 380-386.

Zelilidis, A., Koukouvelas, I., Doutsos, T. 1988. Neogene paleostress changes behind the forearc fold belt in the Patraikos Gulf area, Western Greece. Neues Jahrbuch für Geologie und Paläonologie. Mh, Stuttgar, pp. 311-325. 